\title{
A Review of the Potential Use of Entomopathogenic Nematodes to Control Above-Ground Insect Pests in South Africa
}

\author{
T. Platt ${ }^{1}$, N.F. Stokwe ${ }^{1,2}$, A.P. Malan ${ }^{*}$ \\ (1) Department of Conservation Ecology and Entomology, Stellenbosch University, Private Bag X1, Matieland 7602, South \\ Africa \\ (2) ARC Infruitec-Nietvoorbij, Private Bag X5026, Stellenbosch 7599, South Africa
}

Submitted for publication: June 2019

Accepted for publication: August 2019

Key words: Above-ground application, entomopathogenic nematodes, foliar application, Heterorhabditidae, Steinernematidae

\begin{abstract}
Entomopathogenic nematodes (EPNs), of the families Steinernema and Heterorhabditis, are insect parasites that have been successfully used as biological control agents of soil-based insect pests on the North American and European continents. The success of nematodes as biological control agents of the soil stages of pest insects has led to research into their use for control of above-ground insect pests. Laboratorybased studies have shown exceptionally good control, in most cases, against such pests as mealybugs, codling moth and leaf miners. As the life stages of the above-ground insect pests have not co-evolved together with those of EPNs, they are, generally, more susceptible than the soil-based life stages. However, EPNs are susceptible to desiccation and vulnerable to UV radiation, so that ensuring their survival beyond soil environments is problematic. The impetus to avoid environmental stressors can cause EPNs to seek sheltered, cryptic habitats on foliage, where their target insect pest (such as mealybugs) may be found. The current paper provides an overview of information on the application of EPNs as a biocontrol agent for the control of insect pests above ground and on foliage, with particular reference to research done in South Africa.
\end{abstract}

\section{INTRODUCTION}

Entomopathogenic nematodes (EPNs) from the order Rhabditida (Heterorhabditidae and Steinernematidae) are characterised by their exclusive pathogenicity to insects via their mutualism with symbiotic bacteria (Griffin et al., 2005). Various nematode families have been investigated as potential biocontrol agents, with over 30 having been linked to insects in some way (Kaya \& Stock, 1997). However, current research focuses almost entirely on Steinernematidae and Heterorhabditidae (Grewal et al., 2005). The infective juvenile (IJ) stage, which is the free-living, non-feeding survival stage of the EPN life cycle, can easily be masscultured, formulated, and applied as a biological control agent for use against pest insects (Ferreira \& Malan, 2014b; Campos-Herrera, 2015; Kagimu et al., 2017).

Since the first implementation of EPNs as biological control agents of soil-based insect pests, investigations have been performed into their ability to control pest insect life stages found above ground. In particular, the success of EPN formulated products for soil application, as well as their above-ground application in the greenhouse production of crops (Shapiro-Ilan et al., 2006; Lacey \& Georgis, 2012; Kutamanyane et al., 2018), has rekindled an interest in their commercial field application against above-ground insect pests (Arthurs et al., 2004; Le Vieux \& Malan, 2013a; Platt et al., 2018; 2019a, b). However, as soil-adapted organisms, EPNs are poorly suited to above-ground environments, which often feature low relative humidity, extremes of temperature, and exposure to ultraviolet (UV) radiation. The above-mentioned factors result in rapid desiccation and death, negatively impacting on EPN's efficacy as biocontrol agents. The main factor appears to be humidity, with nematode survival being prolonged in humid environments (such as in rainforests or glasshouses) and curtailed in drier (i.e. Mediterranean or southern African) climates (Arthurs et al., 2004).

Methods of improving EPN survival in above-ground environments are currently being investigated. Such methods include weather forecasting (De Luca et al., 2015), early morning or late afternoon application (De Waal et al., 2017), the addition of adjuvants (such as superabsorbent polymer formulations) (Shapiro-Ilan et al., 2010; De Waal et al., 2013), and pre- and post-application wetting (De Waal et al., 2010; Odendaal et al., 2016a), aimed at maximising the humidity levels experienced during and following

*Corresponding author: E-mail address: apm@sun.ac.za

Acknowledgements: The authors would like to thank Winetech, the South African Table Grape Industry (SATI), the National Research Foundation (NRFTHRIP: TP14062571871), and the Agricultural Research Council (ARC) for funding of the project 
application. De Waal et al. (2017) verified the positive effect of applying nematodes in the late evening and early morning against codling moth in a pear orchard in South Africa. The addition of antidesiccants and surfactants to EPN foliar sprays has led to many examples of the enhancement of nematode efficacy (Glazer et al., 1992a; Head et al., 2004; De Waal et al., 2013; Van Niekerk \& Malan, 2014b).

In South Africa the grapevine mealybug, Planococcus ficus (Signoret), citrus mealybug, Planococcus citri (Risso), and the obscure mealybug, Pseudococcus viburni (Signoret), are important insect pests of grapevines, deciduous fruit and citrus, as their presence on export fruit results in rejection of consignments on phytosanitary grounds in many markets. EPNs are non-toxic and able to actively seek out hosts such as mealybugs in grape bunches (Lacey \& Georgis, 2012), therefore they might be a promising alternative for mealybug control on table grapes destined for export, due to restrictions on the presence of chemical residues.

In the current review, available information on the aboveground application of nematodes is brought into context in terms of the control of key insect pests in South Africa, with special reference to the control of mealybugs on grapevines.

\section{ENTOMOPATHOGENIC NEMATODES}

\section{Life cycle}

EPNs belonging to the families Steinernematidae and Heterorhabditidae have been applied with great success as a biocide against a wide range of insect pests (Campos-Herrera, 2015). Both families have similar traits and life cycles, despite not being closely related (Blaxter et al., 1998), with the bacterial symbiont of Steinernema species belonging to the genus Xenorhabdus, whereas Heterorhabditis is associated with Photorhabdus (Griffin et al., 2005). Steinernematids and heterorhabditids have a free-living stage, called the infective juvenile (IJ), also known as the dauer juvenile. This stage occurs freely in the soil, where the IJs can actively seek out and find a suitable insect host.

\section{Occurrence and distribution in South Africa}

The first EPN recorded in South Africa was Steinernema carpocapsae, isolated from the black maize beetle, Heteronychus arator Fabricius (Coleoptera: Scarabaeoidea), collected from a maize field near Grahamstown in the Eastern Cape province (Harington, 1953). During the 1980's unidentified EPNs were applied to the above-ground larval stages of the sugarcane borer, Eldana saccharina Walker (Spaull, 1992).

An investigation into biological control of the banded fruit weevil, Phlyctinus callosus (Schönerr) (Coleoptera: Curculionidae), from 1993 to 1994 yielded a heterorhabditid EPN species that was later confirmed to be Heterorhabditis bacteriophora Poinar (Grenier et al., 1996a, b). Since the first new EPN species from South Africa was described in 2006 as Steinernema khoisanae Nguyen, Malan \& Gozel (Nguyen et al., 2006), several other new species have been described and their occurrence recorded. To date, 16 EPN species have been reported from South Africa, of which five are heterorhabditids, and 11 are steinernematids. Three of the five species of heterorhabditids and 10 of the 11 species of steinernematids were new species at the time of reporting
(Malan et al., 2016; Hatting \& Malan, 2017; Steyn et al., 2017a, b).

\section{Use in above-ground biological control}

EPNs have been successfully commercialised for use against insect pests in North America, Europe, Japan, China, and Australia (Ehlers, 1996; Kaya et al., 2006). Elsewhere research is still in relatively preliminary stages (Kaya et al., 2006). The most widely used commercial applications of EPNs have been aimed at the soil-based stages of insects (Wilson \& Gaugler, 2004). Above-ground application against foliage-feeding insects has been rare, and has generally proved to be less successful than soil-based applications (Shapiro-Ilan et al., 2006).

Arthurs et al. (2004) conducted a meta-study of 136 trials on above-ground application of Steinernema carpocapsae (Weiser) Wouts, Mráček, Gerdin \& Bedding, which has been the most commonly used species to control aboveground insect pests. The study showed that EPN efficacy tends to vary according to the targeted habitat. The most favourable habitat was boreholes (tunnels made by boring insects into leaves, stems, etc.), followed by cryptic habitats (micro-environments on the foliage of plants, sheltered from the environment by bark, leaves, or other structures), with exposed habitats (habitats open to the environment) being the least successful. EPN efficacy also varied according to trial location, with laboratory application (most controlled environment) generally being the most successful, followed by greenhouse application, with field application (the leastcontrolled application) the least successful.

Most studies that have been undertaken with aboveground application of EPNs to control insects have targeted the order Lepidoptera, whereas a smaller number of studies targeted Coleoptera, Diptera, Hemiptera, Hymenoptera, and Thysanoptera (Table 1). The above-ground stages of insects can be targeted with nematodes in different macro environments, such as covered areas like shade houses and glasshouses, or in large-scale field trials, whereas the microhabitat of the insect itself can be boring, cryptic, or exposed (Table 2).

\section{Above-ground application of EPNs by insect order \\ The following sections discuss the prominent insect orders investigated for control with entomopathogenic nematodes, with a focus on the South African context.}

\section{Coleoptera}

As major pests, coleopteran insects have been a significant focus for biological control using EPNs. Steinernema feltiae (Filipjev, 1934) Wouts, Mráček, Gerdin \& Bedding was found to be ineffective for controlling the overwintering larval populations of large European elm bark beetle Scolytus scolytus (Fabricius) (Coleoptera: Curculionidae) at the doses applied (Finney \& Walker, 1979). Testing a variety of EPN species against Stethobaris nemesis (Prena \& O'Brien) (Coleoptera: Curculionidae) on leaf discs in the laboratory, Shapiro-Ilan \& Mizell (2012) found that S. feltiae and $S$. carpocapsae both caused high levels of $S$. nemesis mortality.

Application of $S$. carpocapsae in an agar solution to 
$\ddot{\widetilde{\alpha}}$

$\stackrel{\infty}{\stackrel{\infty}{c}}$

$\underset{\sim}{\widetilde{2}}$

$\stackrel{2}{a}$

ฮี ฮ

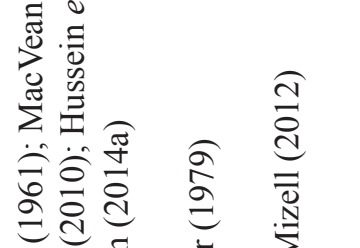

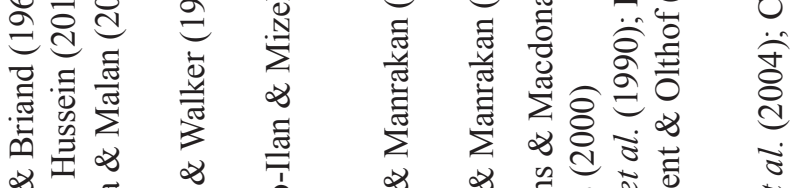

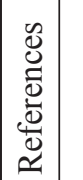

$\hat{\varnothing}$

की

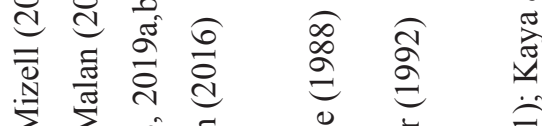

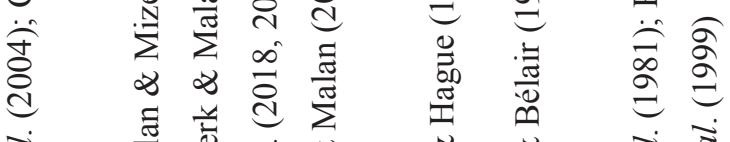

a

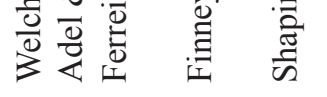

击

宽

言 Z

₹

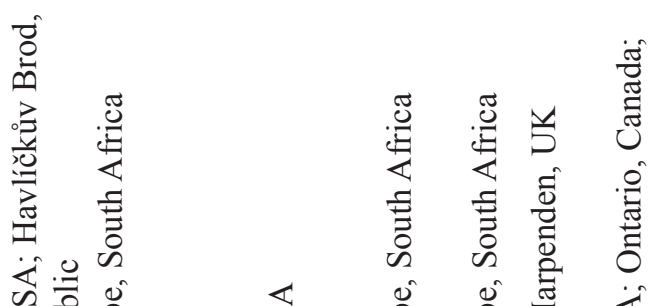

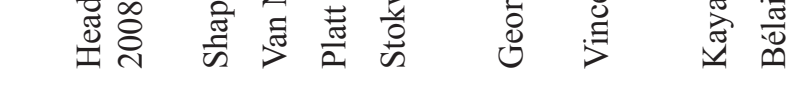

出言芯

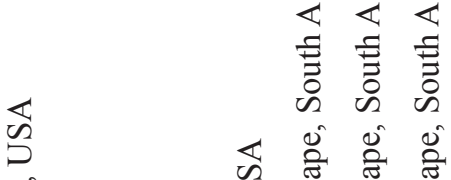

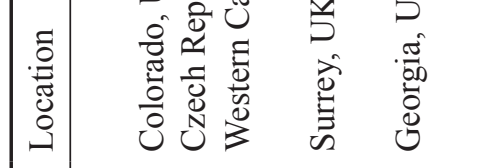

节范 :

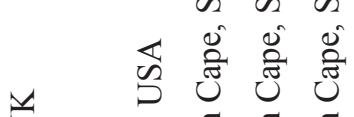

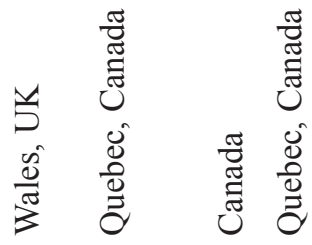

2

.艹

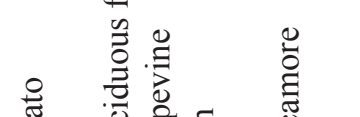

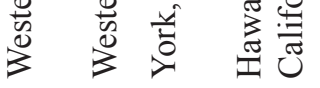

苛

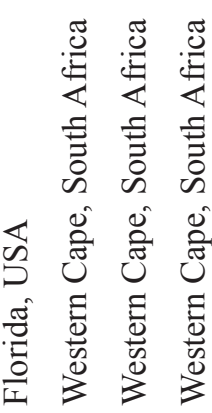

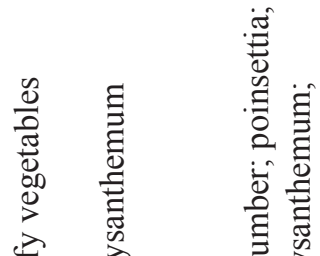

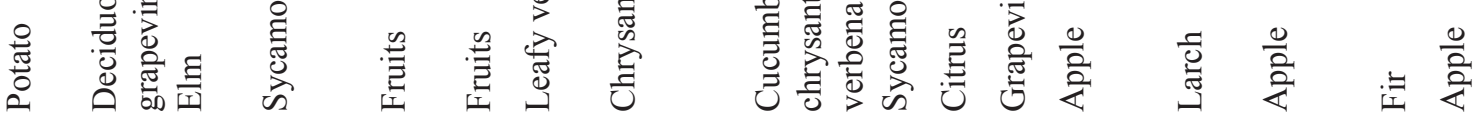

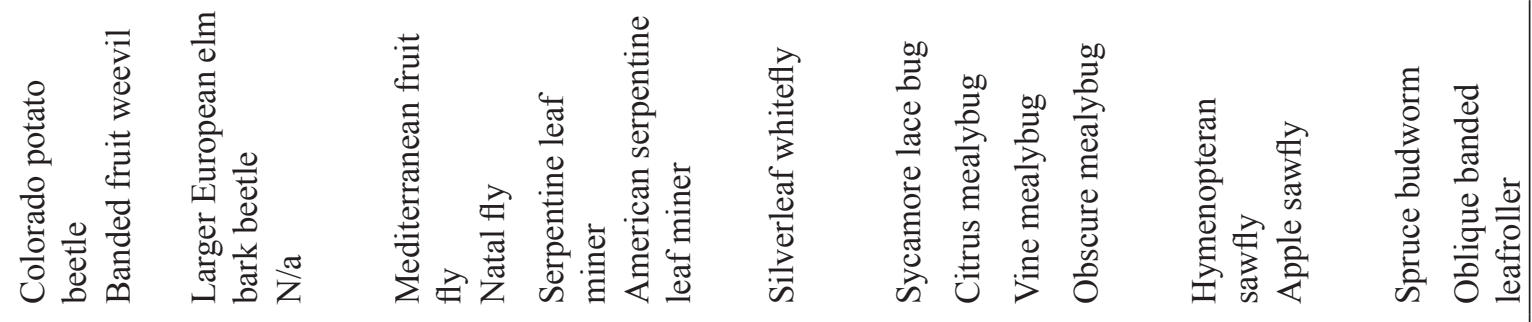

胥

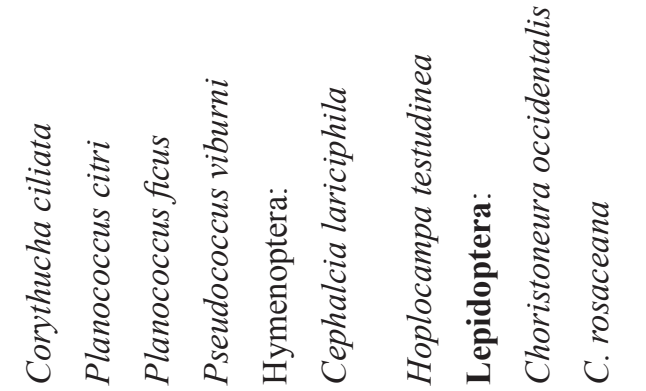


高官

$\hat{\alpha} \approx$

希芯

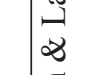

过

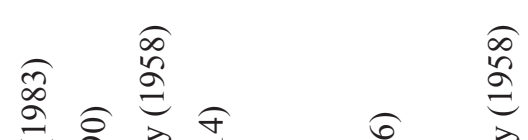

चे

๙ิ ฮี

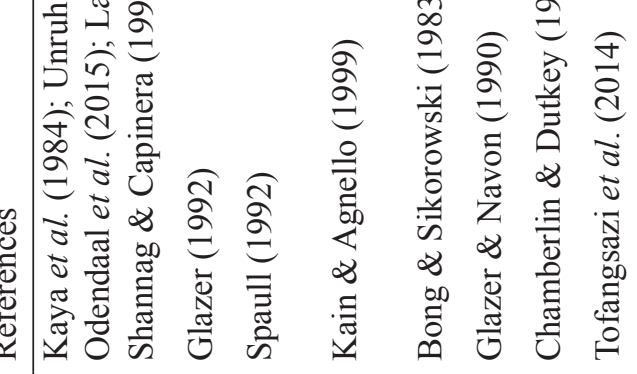

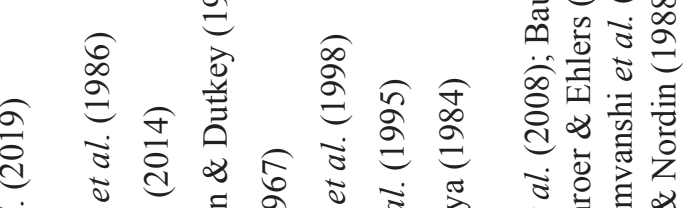

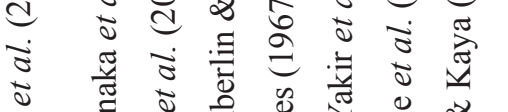

ธे

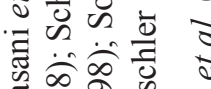

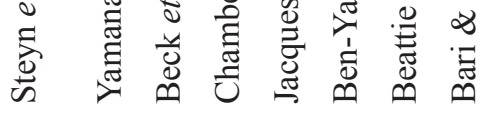

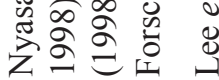

吾

䒴

竞

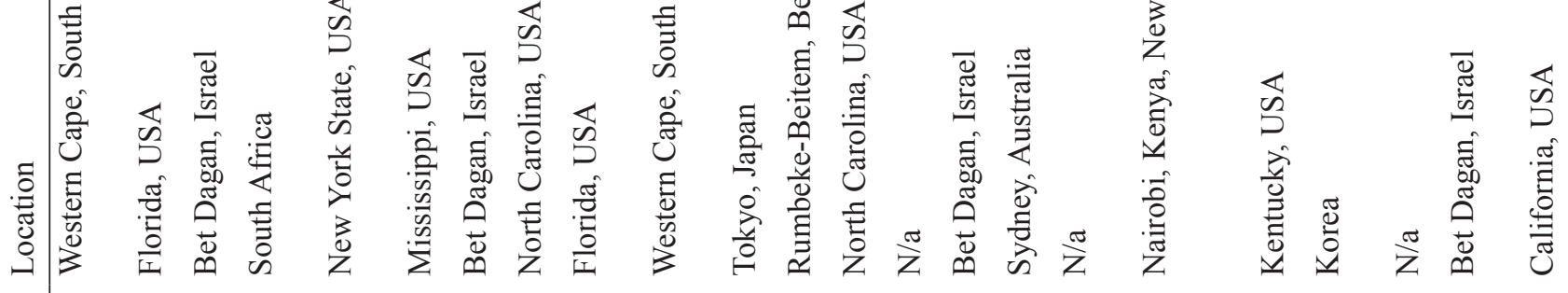

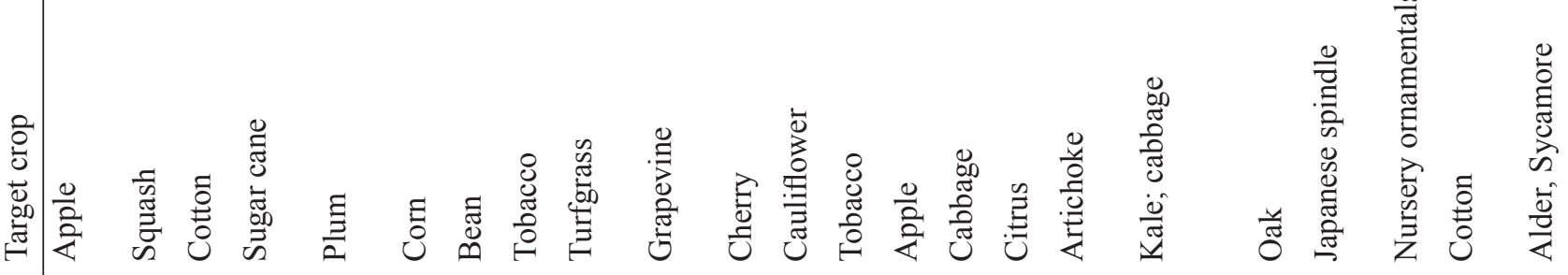

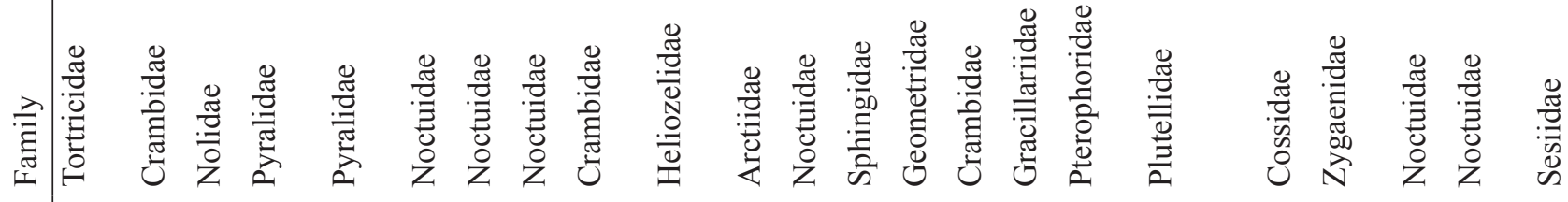

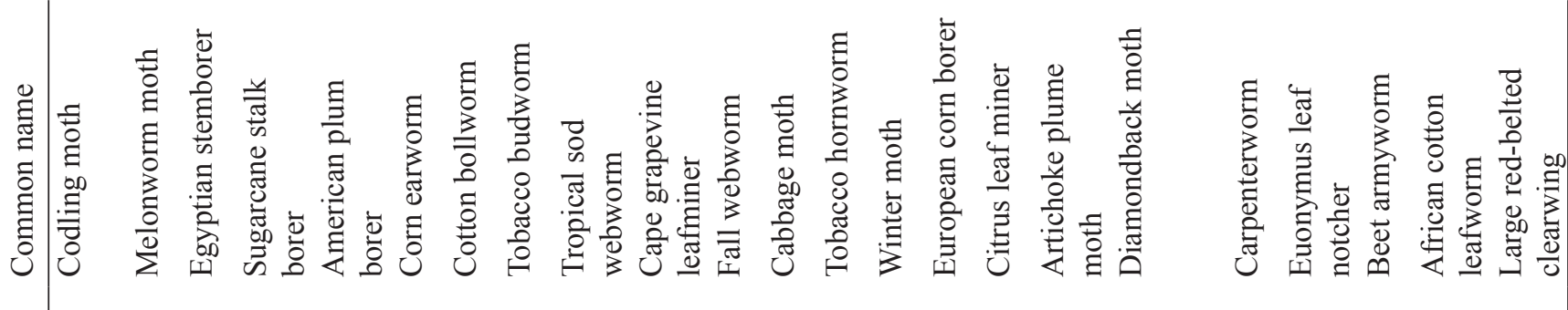

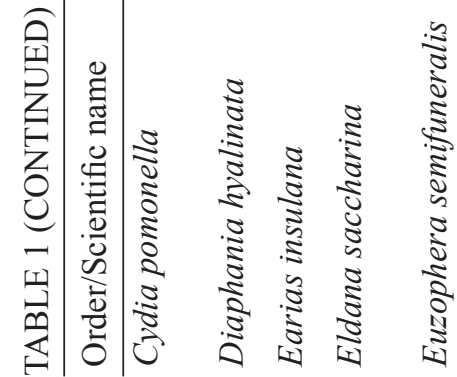

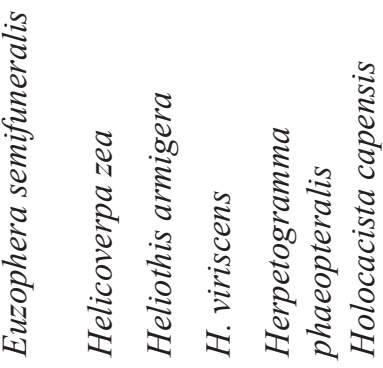

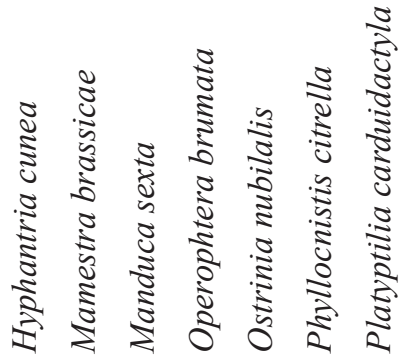

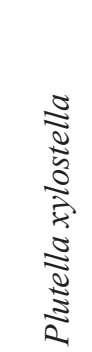

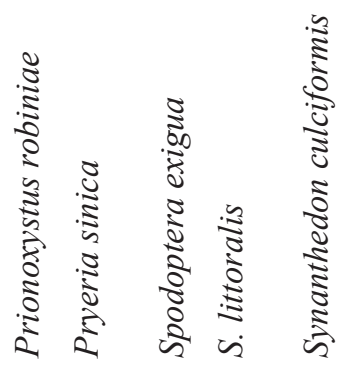




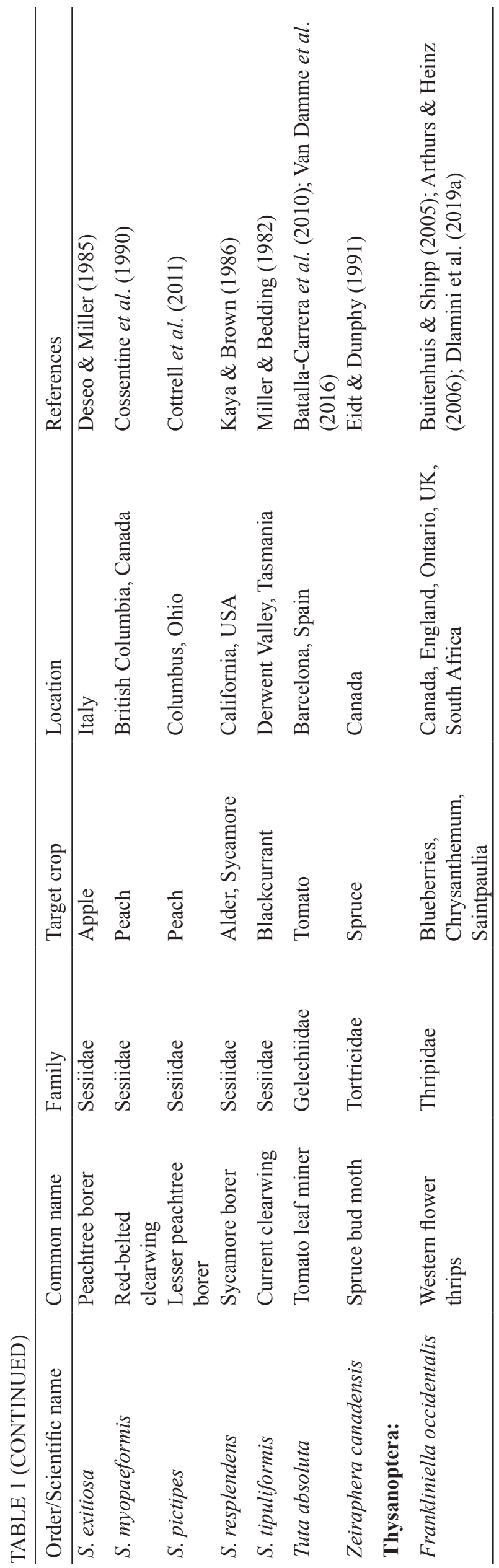

potato foliage resulted in infection rates of $30 \%$ to $60 \%$ of adult Colorado potato beetles, Leptinotarsa decemlineata (Say) (Coleoptera: Chrysomelidae) (MacVean et al., 1982). The addition of agar to the suspension increased the viability and infectivity of the nematodes, resulting in a significant reduction in the amount of leaf damage caused by L. decemlineata (Adel \& Hussein, 2010; Hussein et al., 2012).

In South Africa, the indigenous banded fruit weevil (Phlyctinus callosus Schönerr) (Coleoptera: Curculionidae) tends to emerge above ground during late spring and early summer (Myburgh et al., 1973) in vineyards and orchards, where it is a serious pest. Ferreira \& Malan (2014a) tested the pathogenicity of indigenous Heterorhabditis zealandica (Poinar) (Rhabditida: Heterorhabditidae) and $H$. bacteriophora to adults of the banded fruit weevil in the laboratory. Application of high EPN concentrations (400 IJs/ insect) under optimum conditions and an exposure time of four days resulted in $41 \%$ to $73 \%$ mortality of banded fruit weevil larvae and $13 \%$ to $45 \%$ mortality of adult weevils.

\section{Diptera}

Harris et al. (1990) showed that applications of S. carpocapsae achieved mortality levels of 64\% in larvae of the American serpentine leaf miner, Liriomyza trifolii (Burgess) (Diptera: Agromyzidae), on chrysanthemum, which was similar to control with the insecticide and anthelminthic abamectin. Further investigation by LeBeck et al. (1993) determined that all larval instars of L. trifolii were susceptible to $S$. carpocapsae, but that the second instar is the most susceptible. However, research conducted on control of L. trifolii on lima beans (Hara et al., 1993) and chrysanthemums (Broadbent \& Olthof, 1995) primarily found that abamectin was more effective than $S$. carpocapsae.

Williams \& Walters $(1994,2000)$ showed that all larval instars of the leafminer, Liriomyza huidobrensis (Blanchard) (Diptera: Agromyzidae), were susceptible to S. feltiae, with the second larval instar the most susceptible at conditions of relatively low humidity (Williams \& Macdonald, 1995). Williams \& Walters (2000) consolidated the aforementioned research by applying $S$. feltiae to Chinese cabbage plants infested with L. huidobrensis. They achieved $82 \%$ mortality of L. huidobrensis, a significant increase over mortality previously achieved with the insecticide heptenophos $(\approx 20 \%)$.

The global importance of fruit fly has prompted investigations into the use of EPNs for biocontrol (Langford et al., 2014; Nouh \& Hussein, 2014; Abbas et al., 2016). Laboratory studies have shown the potential of EPNs as biological control agents of many species in the genera Anastrepha, Dacus, Bactrocera, Rhagoletis and Ceratitis, focusing on the susceptibility of the third larval instar. Research in South Africa has been limited, but Mediterranean fruit fly, Ceratitis capitata (Wiedemann), and Natal fruit fly, Ceratitis rosa (Karsch) (Diptera: Tephritidae), were tested for vulnerability to local EPNs. Although adult flies (i.e. the above-ground stage) of both species were found to be susceptible to EPNs, they were less susceptible than the soil-based third instar larvae, indicating that soil-based EPN 
Above-ground Application of Entomopathogenic Nematodes

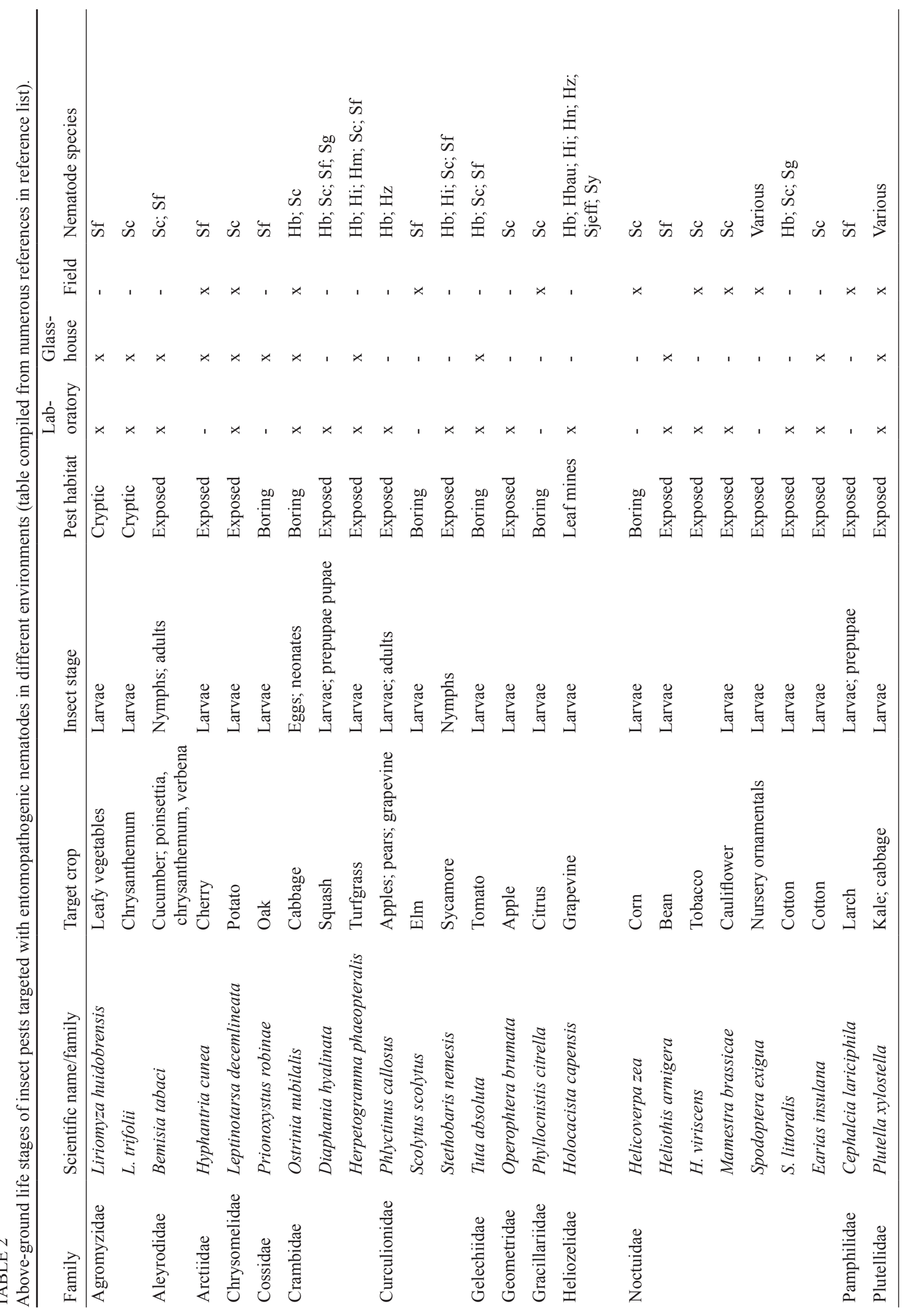




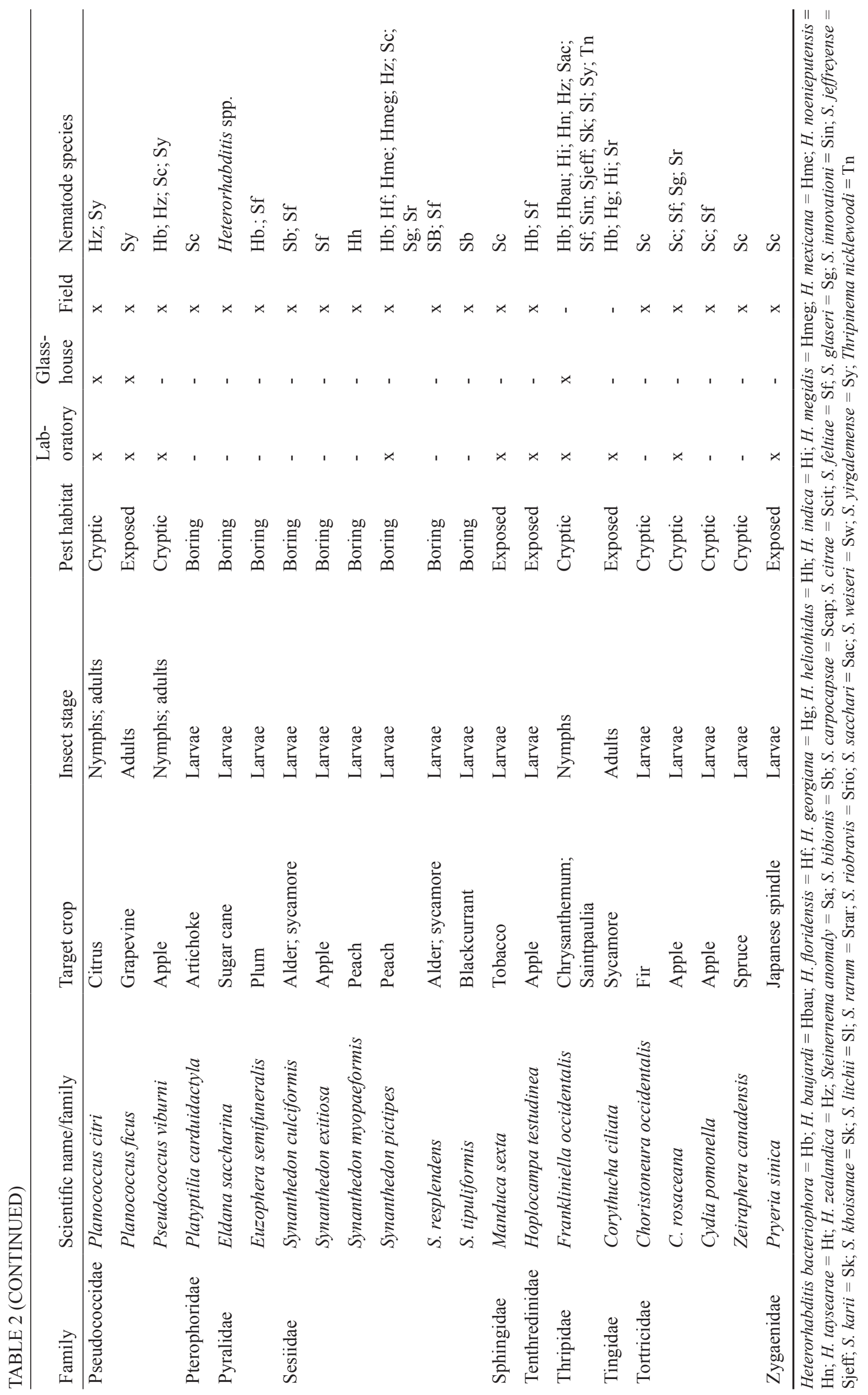


applications are probably more feasible (Malan \& Manrakan, 2009; James et al., 2018).

\section{Hemiptera}

Investigations into the use of $S$. feltiae to control the silverleaf whitefly, Bemisia tabaci (Gennadius) (Hemiptera: Aleyrodidae), found that $S$. feltiae was unable to achieve significant control of $B$. tabaci by itself (inducing pest mortality of between $10 \%$ and $32 \%$ on tomato, cucumber, verbena, poinsettia and chrysanthemum), but the efficacy of the EPN application could be enhanced by $15 \%$ to $31 \%$ with the use of adjuvants (Head et al., 2004). Combining applications of $S$. feltiae with imidacloprid provided significantly more comprehensive control than the use of either treatment alone (Cuthbertson et al., 2007). ShapiroIlan \& Mizell (2012) showed that five species of EPNs, but particularly Heterorhabditis indica Poinar, Karunakar \& David, had potential as biocontrol agents for the sycamore lace bug, Corythucha ciliata (Say) (Hemiptera: Tingidae), a hemipteran pest of ornamental plants.

Mealybugs (Pseudococcidae) are among the most important pests in South African agriculture, and research to develop methods of foliar application of EPNs against them is ongoing. Planococcus citri (Risso) is a major pest of citrus (Hattingh \& Moore, 2003), Planococcus ficus (Signoret) is a major pest of grapevines (Walton, 2003) and the obscure mealybug, Pseudococcus viburni (Signoret), is regarded as the main mealybug pest of deciduous fruit (Prinsloo \& Uys, 2015).

Van Niekerk \& Malan (2012) screened potential EPN candidates for the foliar control of $P$. citri, finding Steinernema yirgalemense Nguyen, Tesfamariam, Gozel, Gaugler \& Adams and $H$. zealandica to be the most effective nematode species. They then tested both species in combination with various agrochemicals and natural enemies, in response to which neither species was shown to decrease in infectivity. Both EPN species were, however, highly infective to the larvae of the ladybird Cryptolaemus montrouzieri (Coleoptera: Coccinellidae) (Mulsant), which is a biocontrol predator of $P$. citri, indicating that these organisms should not be used together in an IPM system (Van Niekerk \& Malan, 2014a).

Van Niekerk \& Malan (2015) investigated the use of adjuvants to overcome a key obstacle to the application of EPNs to foliage, namely the need to maintain suitable levels of relative humidity $(\mathrm{RH})$ to allow for EPN infection of the citrus mealybug. Application of the adjuvant Zeba ${ }^{\circledR}$ ( $3 \mathrm{~g} / \mathrm{L})$ increased the effectiveness of $H$. zealandica against $P$. citri by $22 \%$ at $80 \% \mathrm{RH}$, with the combination of both Zeba $^{\circledR}$ and Nu-Film-P ${ }^{\circledR}$ significantly increasing the amount of nematodes deposited on the leaves. In a semi-field trial in a citrus orchard, significantly higher levels of control $(53 \%)$ were achieved by adding Zeba ${ }^{\circledR}$. The study showed that the addition of an adjuvant improved the ability of $S$. yirgalemense to infect $P$. citri by retarding desiccation and by buffering the nematodes from the harsh environmental conditions (Van Niekerk \& Malan, 2014b).

In South Africa, Le Vieux \& Malan (2013a, b; 2015) demonstrated high susceptibility of adult $P$. ficus to six different indigenous EPN species (with $S$. yirgalemense the most promising) in laboratory studies, and olfactometer studies indicated that $S$. yirgalemense actively moves towards the vine mealybug, which could prove advantageous for finding mealybugs in their cryptic habitats prior to desiccation. Platt et al. (2018) recently also showed that $P$. ficus females are highly susceptible to four South African EPN species, with the highest mortality of $90 \%$ caused by Heterorhabditis noenieputensis Malan, Knoetze \& Tiedt in laboratory bioassays. They also showed that a combination of $\mathrm{Nu}-\mathrm{Film}^{\circledR}$ and $\mathrm{Zeba}^{\circledR}$ increased the deposition of $S$. yirgalemense on grapevine leaves. Results from a growth chamber bioassay, using grapevine leaves, showed $84 \%$ mortality of $P$. ficus females when combined with the two adjuvants, while in a glasshouse trial $88 \%$ mortality of $P$. ficus females was obtained (Platt et al., 2019a). Steinernema yirgalemense was also tested in a semi field trial in a vineyard, combined with adjuvants, causing $66 \%$ female mortality, which varied with the nematode concentration and the time of application during the day (Platt et al., 2019b). The high susceptibility of P. ficus to EPNs and the tendency of mealybugs to form colonies in cryptic habitats above ground make P. ficus an ideal candidate for control using nematodes. EPNs could be applied to target mealybugs on leaves and bunches during the growing season, and after leaf drop to target overwintering mealybugs under the bark on vine cordons and stems.

Steinernema yirgalemense Stokwe \& Malan (2016) investigated the ability of EPNs to control P. viburni, one of three species of pseudococcids that are commonly found on pome fruit in the Western Cape province of South Africa (Wakgari \& Giliomee, 2004). The researchers found that $H$. zealandica and $S$. yirgalemense were both able to reproduce in $P$. viburni, with the former displaying greater mealybug penetration, and also possessing the ability to infect $P$. viburni at the centre of infested apple cores, making it a potential candidate for the above-ground control of P. viburni in both apple and pear orchards.

\section{Hymenoptera}

To date, most research into the application of EPNs for the control of hymenopteran pests of foliage has focused on sawflies, outside the South African context. On evaluating $S$. feltiae for use against the web-spinning larch sawfly, Cephalcia lariciphila (Wachtl) (Hymenoptera: Pamphiliidae), in Welsh larch, Georgis \& Hague (1988) found the infection of the larval stages to be prohibitively low when compared to application, at equivalent rates, to prepupae in the soil (3\% to $39 \%$ versus $61 \%$ infection, respectively).

Vincent \& Bélair (1992) took a similar approach, applying $S$. carpocapsae to dwarf apple trees in efforts to control the apple sawfly, Holocampa testudinea (Klug) (Hymenoptera: Tenthredinidae). The application of EPNs in this case was not found to significantly reduce the amount of primary damage, i.e. scarring of fruit as a result of sawfly burrowing into fruit. However, it did significantly reduce the amount of secondary damage incurred, in terms of the number of frass pellets deposited at the entry point of burrowing. Further research by Vincent \& Bélair (1992) assessed the application of $S$. carpocapsae against $H$. testudinea over a period of three years. The amount of primary damage inflicted on the apple 
fruit by $H$. testudinea was reduced by $98 \%$ and $100 \%$ in the first two years, respectively, while the percentage of fruits exhibiting secondary damage was significantly reduced after a single application of $S$. carpocapsae. The effectiveness of the treatment was attributed to the cages used, which increased the $\mathrm{RH}$, and, therefore, the extent of nematode longevity and mobility.

\section{Lepidoptera}

The research conducted by Bélair et al. (1999) into the application of $S$. carpocapsae against the oblique banded leafroller, Choristoneura rosaceana (Harris) (family Tortricidae), a pest of apples, concluded that the low efficacy of the nematode and the inability of the selected adjuvants to improve nematode efficacy indicated that the use of $S$. carpocapsae as a sole agent against the leafroller could not be recommended. On assessing the efficacy of $S$. carpocapsae in controlling the Western spruce budworm, Choristoneura occidentalis (Walsingham) (Tortricidae), in fir, Kaya \& Reardon (1982) concluded that significant infectivity of the insect larvae and pupae could not be obtained, despite the use of adjuvants and the bagging of treated branches to enhance the extent of nematode survivability.

Cydia pomonella, the codling moth, has been a major target of research in terms of the foliar application of EPNs, due to its status as a serious pest of apples worldwide. The application of $S$. feltiae to codling moth diapausing larvae in corrugated cardboard on apple tree trunks resulted in $80 \%$ codling moth mortality in mid-autumn, with $32 \%$ mortality resulting therefrom in midsummer (Kaya et al., 1981). Unruh \& Lacey (2001) assessed the effect of applying a variety of methods to increase the infectivity of S. carpocapsae to codling moth larvae trapped in cardboard traps in apple orchards in Washington, USA. Their findings revealed that the application of EPNs to traps containing codling moth larvae was most effective under the relatively cool and humid conditions prevailing in the morning and evening, as well as in the case of both the pre- and postwetting of the treatments. Odendaal et al. (2015) performed an investigation into the ability of South African EPNs to control codling moth in South African environments, by assessing the effectivity of the local species Steinernema jeffreyense Malan, Knoetze \& Tiedt and S. yirgalemense in relation to the commercially available nematodes $S$. feltiae and two strains of $H$. bacteriophora. The researchers found that $S$. jeffreyense showed the highest efficacy (67\%) when it was applied to codling moth larvae kept in small mesh cages. No adjuvants were added in the above-mentioned trials, with the cages merely being sprayed with water every $2 \mathrm{~h}$ for the first $6 \mathrm{~h}$ of the trial. This study indicates the potential for South African nematodes to be effective, if conditions of high humidity can be maintained.

Codling moth infestations have been shown to be persistent due to the contamination of fruit bins in orchards, even when other control methods were in place. On examining the ability of $S$. carpocapsae and $S$. feltiae to control the infestation of orchard fruit bins, Lacey et al. (2005) found that both species provided high mortality of cocooned codling moth larvae when they were applied together with wetting agents.
Two studies have been conducted in South Africa to determine the potential of EPNs to control codling moth infestations of wooden fruit bins. Using $25 \mathrm{IJs} / \mathrm{mL}$ as a discriminating dosage in laboratory trials, De Waal et al. (2010) determined the $\mathrm{LD}_{90}$ of codling moth to be $100 \mathrm{IJ} / \mathrm{mL}$, using miniature bins under optimum conditions. The study also indicated that conditions of high humidity are crucial for obtaining the desired control, and that covering the bins with a tarpaulin, together with the use of adjuvants, improved the level of control significantly. Further studies by Odendaal et al. $(2016 \mathrm{a}, \mathrm{b})$ evaluated the efficacy of $S$. yirgalemense, a local isolate, and two commercial isolates, $S$. feltiae and $H$. bacteriophora, for their potential to control codling moth in miniature bins at a concentration of $25 \mathrm{IJs} / \mathrm{ml}$. The best control (75\%) was obtained with $S$. feltiae, and the degree of control was significantly increased to $>95 \%$ by the addition of adjuvants.

The diamond back moth, Plutella xylostella L. (Lepidoptera: Plutellidae) is a serious pest of cabbage and other crucifers. In laboratory trials, the $\mathrm{LD}_{50}$ for P. xylostella was found to be $12 \mathrm{~S}$. carpocapsae larvae per insect (Zolfagharian et al., 2014). Field trials in Cuba, Marrero (2006) obtained $72 \%$ control with a spray application of $H$. indica, while Rodríguez et al. (2013) also showed a reduction in the number of $P$. xylostella on cabbage with H. bacteriophora in another trial.

Stem-boring lepidopteran larvae are attractive candidates for EPN application, as they obtain protection from harsh environmental conditions by means of boring tunnels or galleries into stems and leaves. Chief among these are the sesiids (Lepidoptera: Sesiidae), which are mostly obligate borers of plant stems. Kaya \& Brown (1986) investigated the ability of $S$. feltiae to control the large red-belted clearwing, Synanthedon culciformis (Linnaeus) (Lepidoptera: Sesiidae), on alder, and the sycamore borer, S. resplendens (Edwards) (Lepidoptera: Sesiidae), on sycamore. The researchers found $S$. feltiae to be more effective against $S$. culciformis when it was applied directly to the borer galleries, due to the $S$. culciformis residing in the alder heartwood, which was moister than the sycamore heartwood. Deseo \& Miller (1985) performed similar experiments, applying $S$. feltiae to apple trees in Italy to control two strains of red-belted clearwing, Synanthedon myopaeformis (syn. S. typhiaeformis) (Borkhausen) (Lepidoptera: Sesiidae). They concluded that the two specific strains of $S$. feltiae were capable of actively seeking out, and of migrating towards, S. myopaeformis.

The effects of EPNs against sesiids on peach have also been assessed. Cossentine et al. (1990) applied $H$. bacteriophora (heliothidus strain) to control the peach tree borer, Synanthedon exitiosa (Say) (Lepidoptera: Sesiidae), finding that a suspension of EPNs in and around the boreholes failed to reduce the number of adults emerging from the holes significantly. Cottrell et al. (2011), in testing several EPN species for efficacy against the lesser peach tree borer, Synanthedon pictipes (Grote \& Robinson) (Lepidoptera: Sesiidae), compared two adjuvants (polyacrylamide gel and moistened baby diapers) with the aim of improving moisture retention and UV protection. Both adjuvants were found to improve the control of $S$. pictipes compared to the control. Shannag \& Capinera (1995) assessed five EPN species for 
the control of melonworm, Diaphania hyalinata (Linnaeus) (Lepidoptera: Crambidae), applying $S$. carpocapsae against D. hyalinata on squash foliage. Survival of EPNs on foliage was limited to only $0.25 \%$ after 18 hours under moderately humid conditions, however, this limited survival on foliage did not appear to impair infectivity, with field applications of 5 billion nematodes per hectare resulting in infection rates of between $52 \%$ and $55 \%$.

Shapiro-Ilan et al. (2010) applied S. carpocapsae for the control of the late instars of the lesser peach tree borer, S. pictipes (Grote \& Robinson) (Lepidoptera: Sesiidae), with applications of latex paint, moistened diaper, or gel spray post-application of EPNs to enhance nematode survival on the peach tree foliage. The application of Barricade ${ }^{\circledR}$ gel, after nematode application, enhanced the efficacy of $S$. carpocapsae against the peach tree borers on the foliage. Further research established that Barricade ${ }^{\circledR}$ could be used in a single-spray together with $S$. carpocapsae, and that the combination was at least as successful as chlorpyrifos against the lesser peach tree borer (Shapiro-Ilan et al., 2016). The susceptibility of different life stages of the South American tomato leafminer, Tuta absoluta (Meyrick) (Lepidoptera: Gelechiidae) to various EPN species has been tested with a view to foliar application. Van Damme et al. (2016) showed in laboratory studies that all the insect instars were susceptible to infection by $S$. feltiae, H. bacteriophora and $S$. carpocapsae, with $S$. feltiae causing $100 \%$ mortality under optimum laboratory conditions. The researchers found that improvements to spraying conditions and the addition of adjuvants allowed IJ concentrations as low as $6.8 \mathrm{IJ} / \mathrm{cm}^{2}$ to achieve levels of control equivalent to the recommended IJ concentration of $27.3 \mathrm{IJs} / \mathrm{cm}^{2}$ under standard conditions.

Recently it was found that different local EPN species were able to penetrate and infect larvae of the Cape grapevine leafminer, Holocacista capensis Van Nieukerken \& Geertsema (Lepidoptera: Heliozelidae), in their galleries in grapevine leaves. High mortality of $H$. capensis larvae was recorded for Heterorhabditis baujardi Phan, Subbotin, Nguyen \& Moens (92\%), H. noenieputensis (85\%) and H. indica $(83 \%)$ under laboratory conditions (Steyn et al., 2019).

\section{Thysanoptera}

The major thysanopteran pest targeted with EPNs is the western flower thrips, Frankliniella occidentalis (Pergande) (family Thripidae), because it is difficult to control, due to its preference for cryptic habitats on plants. Buitenhuis \& Shipp (2005) assessed the efficacy of S. feltiae, applied in conjunction with a wetting agent, against $F$. occidentalis on chrysanthemums in the flowering versus the vegetative (i.e. exposed) stage. They found no significant differences in mortality of larvae and pupae between the two plant stages, and, in addition, observed no significant mortality of adult thrips. Arthurs \& Heinz (2006), in assessing the applications of $S$. feltiae against thrips on chrysanthemums, failed to reduce the amount of damage caused to the host plant.

In South Africa, 11 local EPN species and the exotic S. feltiae were tested under laboratory conditions for pathogenicity against western flower thrips. Generally, Heterorhabditis spp. were found to be more virulent than
Steinernema spp. The study showed that S. yirgalemense (66\%), H. baujardi (67\%) and H. bacteriophora (60\%) had potential for the control of $F$. occidentalis in terms of targeting its soil-dwelling stages. Results from a temporal development study showed that both $S$. yirgalemense and $H$. baujardi were able to complete their life cycles in the second stage larvae of $F$. occidentalis and to produce a new cohort of IJ (Dlamini et al., 2019a, b).

\section{OVERCOMING CHALLENGES TO ABOVE-GROUND APPLICATION}

The success of EPNs as biocontrol agents depends on their survival and their survival above ground is limited by several environmental factors, including temperature, ultraviolet (UV) radiation, and prevailing moisture/relative humidity (\% RH) levels. This makes above ground applications of EPNs challenging.

\section{Temperature}

As nematodes are highly sensitive to changes in temperature, they must be kept in aqueous solutions ranging in temperature from $4^{\circ} \mathrm{C}$ to $30^{\circ} \mathrm{C}$, with most species being intolerant to temperatures that are higher than $35^{\circ} \mathrm{C}$ for longer than $30 \mathrm{~min}$ at any one time (Grewal et al., 1994). Relatively high temperatures also reduce the solubility of oxygen in solution. Depriving EPNs of oxygen for prolonged periods of time results in their deactivation and in their ultimate death (Wright et al., 2005). Different EPN species also have different thermal niches within which they can infect and establish themselves within their respective hosts. Grewal et al. (1994) listed the temperature niches for various species of nematodes in their interactions with last-instar Galleria mellonella Linnaeus (Tortricidae: Pyralidae) larvae. To minimise the negative effects of temperature, glasshouse and field applications of nematodes should take place either early in the morning or late in the afternoon. Nematodes which are tolerant to low temperatures, like $S$. feltiae, can be selected for use in relatively cool environments.

\section{Ultraviolet (UV) radiation}

Exposure to UV light should be taken into consideration when applying EPNs above ground. UV light and sunlight have both been shown to affect the behaviour and pathogenicity of both plant- (Godfrey \& Hoshino, 1933) and animal-parasitic (Stowens, 1942) nematodes significantly. Gaugler \& Boush (1978) observed the effects of short UV radiation and natural sunlight on $S$. carpocapsae, in terms of their interaction with G. mellonella larvae. They found that exposure of IJs to short-term UV radiation for 7 min caused reduced pathogenicity and increased larval survival time post-infection. Exposure to direct sunlight also reduced their pathogenicity by as much as 95\% after $60 \mathrm{~min}$. Gaugler et al. (1992) found that $S$. carpocapsae IJs were rendered completely inactive after 10 min of moderate UV exposure, whereas $H$. bacteriophora was significantly affected after only $4 \mathrm{~min}$, indicating that the susceptibility to UV light varies across species. In general, nematodes are known to move away from direct sunlight towards cryptic microhabitats. The challenge posed by this vulnerability to UV light could also be avoided with the application of nematodes either early in the morning or 
in the late afternoon, which would give them enough time to move towards the cryptic microhabitat in which the target host is also most likely to reside.

\section{Humidity}

Temperature and UV radiation are contributing factors to the desiccation of IJs when they are applied above ground. However, nematode survival and viability on foliage appears to be directly related to the prevailing RH. Glazer (1992), comparing the survivability of $S$. carpocapsae on bean foliage at $45 \%, 60 \%$ and $80 \% \mathrm{RH}$, showed that nematode survival and pathogenicity both improved at $60 \% \mathrm{RH}$, and with the addition of antidesiccants. Glazer et al. (1992a, b) assessed the survival of $S$. carpocapsae IJs used to control the cotton pests, Earias insulana (Boisduval) (Lepidoptera: Nolidae), Heliothis armigera (Hübner) (Lepidoptera: Noctuidae), and Spodoptera littoralis (Boisduval) (Lepidoptera: Noctuidae) at low RH. The addition of antidesiccants to the nematode solutions applied to cotton plants resulted in between $85 \%$ and $95 \%$ insect mortality, compared to $22 \%$ in the case of the control, as well as a significant decrease in damage to the foliage compared to the control.

From research to date, it can be concluded that one of the possible means of overcoming environmental limitations, particularly humidity, when applying EPNs above ground is the addition of adjuvants to modify the characteristics of the nematode suspension. Adjuvants are broadly defined as additives to pesticide solutions that are intended to increase, or to modify, their effects (Krogh et al., 2003). The United States Environmental Protection Agency also includes safeners and synergists in its definition of adjuvants. In South Africa, guidelines regarding adjuvants are still being developed, while EU regulations refer to both the coformulant and the adjuvant collectively as "adjuvants". The additives are defined more by function than by form, with adjuvant formulations ranging from carbon-chain polymers (e.g. Anti-Stress $2000^{\circledR}$ ), bicyclic oxazolidine $\left(\right.$ Moisturin $^{\circledR}$ ), di-1-p-menthene $\left(\mathrm{Nu}-\mathrm{Film}-17^{\circledR}\right)$, acrylic resin (ShatterProof $^{\circledR}$ ), and polymeric terpene (Transfilm ${ }^{\circledR}$ ) (Shapiro-Ilan et al., 2010).

Determining the toxicity of any adjuvant to the nematodes themselves is very important. Shapiro-Ilan et al. (2010) tested five adjuvants (Anti-Stress $2000^{\circledR}$, Moisturin ${ }^{\circledR}, \mathrm{Nu}-\mathrm{Film}-17^{\circledR}$, Shatter-Proof $^{\circledR}$ and Transfilm ${ }^{\circledR}$ ) at concentrations of $2 \%, 20 \%$ or $40 \%$ for their toxicity to $S$. carpocapsae and showed that the rate of nematode survival only decreased significantly at a concentration of $40 \%$, compared to the control. This concentration far exceeded the recommended concentration of Shatter-Proof ${ }^{\mathbb{B}}(12.5 \%)$, the adjuvant selected for field trials, because it resulted in the lowest numerical mortality of nematodes in suspension.

Adjuvant efficacy varies on a case-by-case basis. In testing several adjuvants in combination with EPNs for the control of the diamondback moth, Plutella xylostella Linnaeus, Baur et al. (1997) found that, whereas the adjuvants tested served to increase the pathogenicity of the nematodes, the overall benefit attained was probably insufficient to warrant the use of EPNs against this pest. The researchers also observed that several of the adjuvants tested were phytotoxic to radish leaves, highlighting the importance of screening adjuvants not only for efficacy and for nematode mortality, but also for host plant toxicity.

The availability of a variety of adjuvants in the form of surfactants, gels and polymers is an area that remains to be actively explored (Shapiro-Ilan \& Mizell, 2012; Malan \& Hatting, 2015). Mixing nematode suspensions with such adjuvants, or with a combination of such adjuvants, should facilitate the use of the biocontrol agents in above-ground areas that were previously considered inaccessible for nematode application.

\section{CONCLUSIONS}

EPNs have potential value as a non-toxic alternative to manufactured chemical pesticides, thus allowing producers an additional biological tool with which to control pests in an environmentally sustainable way. Above-ground insects, like mealybugs, are expected, in general, to be relatively susceptible to EPNs, because the latter present a novel predator threat to mealybug against which they could not have evolved defences. EPNs are intensively used under cover in greenhouses and shade houses, in which the conditions tend to be relatively optimal.

Foliage-based pests residing in cryptic habitats above ground, such as beneath bark, in boreholes, or under leaves that are out of the reach of the sun, would appear to be ideal targets for EPNs that require conditions of shade, moderate temperature, and high humidity to survive and be infective. The application of EPNs to insect pests in controlled environments (such as the laboratory and the glasshouse) is evidence of their potential as the biocontrol agents of pests in environments in which the levels of humidity remain high, in which desiccation is relatively slow, and in which nematodes are able to find, and infect, their insect hosts. In contrast, EPNs tend to perform poorly against pests of foliage in the field. The main barrier to the successful application of EPNs in the control of foliar pests has been concluded to be the environment, mainly due to desiccation of EPNs in environments where the humidity cannot be directly controlled.

To counter this, novel application methods have been developed to retard desiccation of foliar-applied EPNs, ranging from the post-application spraying of a gel that was originally used in firefighting, to the envelopment of treated areas with moistened diapers. Simple management practices, such as altering the time of application to either late in the evening or in the early morning, can play an important role in attaining nematode efficacy, as nematodes need only a few hours of optimum conditions to be able to infect the host. In South Africa, an additional challenge is the development of methods to culture local EPN isolates on an industrial scale, which is a pre-requisite for commercialisation. The successful use of EPNs on foliage requires cultural and chemical methodology to be put in place to maximise the persistence and infectivity of EPNs on foliage, be it through time-sensitive application, spray methods, adjuvant formulation or any combination of the three. 


\section{LITERATURE CITED}

Abbas, M.S.T., Noughm, G.M., Abdel-Samad, S.M. \& Negm, A.A., 2016. Infectivity of the entomopathogenic nematodes as biocontrol agents to Spodoptera littorals, Ceratitis capitata and Bactrocera zonata. Egypt J. Biol. Pest. Con. 26, 609-613.

Adel, M.M. \& Hussein, H.M., 2010. Effectiveness of entomopathogenic nematodes Steinernema feltiae and Heterorhabditis bacteriophora on the Colorado potato beetle Leptinotarsa decemlineata (Say) (Coleoptera: Chrysomelidae) under laboratory and greenhouse conditions. Arch. Phytopathol. PFL. 43, 1485-1494. doi.org/10.1080/03235400802538473

Arthurs, S. \& Heinz, K., 2006. Evaluation of the nematodes Steinernema feltiae and Thripinema nicklewoodi as biological control agents of western flower thrips Frankliniella occidentalis infesting chrysanthemum. Biocontrol. Sci. Techn. 16, 141-155. doi.org/10.1080/09583150500258545 Arthurs, S., Heinz, K.M. \& Prasifka, J.R., 2004. An analysis of using entomopathogenic nematodes against above-ground pests. B. Entomol. Res. 94, 297-306

Bari, M.A. \& Kaya, H.K., 1984. Evaluation of the entomogenous nematode Neoaplectana carpocapsae (= Steinernema feltiae) Weiser (Rhabditida: Steinernematidae) and the bacterium Bacillus thuringiensis Berliner var. kurstarki for suppression of the artichoke plum moth (Leptidoptera: Pterophoridae). J. Econ. Entomol. 77, 225-229.

Batalla-Carrera, L., Morton, A. \& Garcìa-del-Pino, F., 2010. Efficacy of entomopathogenic nematodes against the tomato leadminer Tuta absoluta in laboratory and greenhouse conditions. BioControl 55, 523-530. DOI:10.1007/s10526-010-9284-Z

Baur, M.E., Kaya, H.K., Gaugler, R. \& Tabashnik, B., 1997. Effects of adjuvants on entomopathogenic nematode persistence and efficacy against Plutella xylostella. Biocontrol Sci. Techn. 7, 513-525.

Baur, M.E., Kaya, H.K., Tabashnik, B.E. \& Chilcutt, C.F., 1998. Suppression of diamondback moth (Lepidoptera: Plutellidae) with an entomopathogenic nematode (Rhabditida: Steinernematidae) and Bacillus thuringiensis Berliner. J. Econ. Entomol. 91, 1089-1095.

Baur, M.E., Kaya, H.K. \& Thurston, G.S., 1995. Factors affecting entomopathogenic infection of Plutella xylostella on a leaf surface. Entomol. Exp. Appl. 77, 239-250.

Beattie, G.A.C., Somsook, V., Watson, D.M., Clift, A.D. \& Liang, J., 1995. Field evaluation of Steinernema carpocapsae (Weiser) (Rhabditida: Steinernematidae) and selected pesticides and enhancers for control of Phyllocnistis citrella Stainton (Lepidoptera: Gracillariidae). J. Aust. Ent. Soc. 34, 335-342.

Beck, B., Brusselman, E., Nuyttens, D., Moens, M., Temmerman, F., Pollet, S., Van Weyenberg, S. \& Spanoghe, P., 2014. Improving the biocontrol potential of entomopathogenic nematodes against Mamestra brassicae: Effect of spray application technique, adjuvants and an attractant. Pest Manag. Sci. 70, 103-112. DOI:10.1002/ps.3533

Begley, J.W., 1990. Efficacy against insects in habitats other than soil. In: Gaugler, R. \& Kaya, H.K. (eds). Entomopathogenic nematodes in biological control. CRC Press, Boca Raton, FL. pp. 215-231.

Bélair, G., Vincent, C., Lemire, S. \& Coderre, D., 1999. Laboratory and field assays with entomopathogenic nematodes for the management of oblique banded leafroller Choristoneura rosaceana (Harris) (Tortricidae). J. Nematol. 31, 684-689.

Ben-Yakir, D., Efron, D., Chen, M. \& Glazer, I., 1998. Evaluation of entomopathogenic nematodes for biocontrol of the European corn borer, Ostrinia nubilalis, on sweet corn in Israel. Phytoparasitica 26, 101-108.

Berlinger, M.J., 1977. The Mediterranean vine mealybug and its natural enemies in southern Israel. Phytoparasitica 5, 3-14.
Blaxter, M.L., De Ley, P., Garey, J.R., Liu, L.X., Scheldeman, P., Vierstraete, A., Vanfleteren, J.R., Mackey, L.Y., Dorris, M., Frisse, L.M., Vida, J.T. \& Thomas, W.K., 1998. A molecular evolutionary framework for the phylum Nematoda. Nature 392, 71-75.

Bong, C.F.J. \& Sikorowski, P.P., 1983. Use of the DD 136 strain of Neoaplectana carpocapsae Weiser (Rhabditida: Steinernematidae) for control of corn earworm (Lepidoptera: Noctuidae). J. Econ. Entomol. 76, 590-593.

Bovey, R., Gartel, W., Hewitt, W.B., Martelli, G.P. \& Vuitennez, A., 1980 Maladies a virus et affections similaires de la vigne. Atlas en couleurs des symptoms. Editions Payot, Lausanne.

Broadbent, A.B. \& Olthof, T.H.A., 1995. Foliar application of Steinernema carpocapsae (Rhabditida: Steinernematidae) to control Liriomyza trifolii (Diptera: Agromyzidae) larvae in chrysanthemums. Environ. Entomol. 24, 431-435.

Buitenhuis, R. \& Shipp, J.L., 2005. Efficacy of entomopathogenic nematode Steinernema feltiae (Rhabditida: Steinernematidae) as influenced by Frankliniella occidentalis (Thysanoptera: Thripidae) developmental stage and host plant stage. J. Econ. Entomol. 98, 1480-1485.

Campos-Herrera, R., 2015. Nematode pathogenesis of insects and other pests: Ecology and applied technologies for sustainable plant and crop protection. Springer International Publishing, Cham.

Chamberlin, F.S. \& Dutkey, S.R., 1958. Tests of pathogens for the control of tobacco insects. J. Econ. Entomol. 51, 560.

Cossentine, J.E., Banham, F.L. \& Jensen, L.B., 1990. Efficacy of the nematode, Heterorhabditis heliolithis (Rhabditida: Heterorhabditidae) against the peachtree borer, Synanthedon exitiosa (Lepidoptera: Sesiidae) in peach trees. J. Entomol. Soc. B.C. 87, 82-84

Cottrell, T.E., Shapiro-Ilan, D.I., Horton, D.L. \& Mizell, R.F., 2011. Laboratory virulence and orchard efficacy of entomopathogenic nematodes against the lesser peachtree borer (Lepidoptera: Sesiidae). J. Econ. Entomol. 104, 47-53. https://doi.org/10.1603/EC10137

Cuthbertson, A.G.S., Mathers, J.J., Northing, P., Prickett, A.J. \& Walters, K.F.A., 2008. The integrated use of chemical insecticides and the entomopathogenic nematode, Steinernema carpocapsae (Nematoda: Steinernematidae), for the control of sweetpotato whitefly, Bemisia tabaci (Hemiptera: Aleyrodidae). Insect Sci. 15, 447-453. DOI:10.1111/j.17447917.2008.00232.x

Cuthbertson, A.G.S., Walters, K.F.A., Northing, P. \& Luo, W., 2007. Efficacy of the entomopathogenic nematode, Steinernema feltiae, against sweetpotato whitefly Bermisia tabaci (Homoptera: Aleyrodidae) under laboratory and glasshouse conditions. Bull. Entomol. Res. 97, 9-14.

Daane, K.M., Bentley, W.J., Walton, V.M., Millar, J.G., Ingels, C.A., Weber, E.A. \& Gispert, C., 2008. New controls investigated for vine mealybug. Calif. Agric. 60, 31-38.

De Luca, F., Clausi, M., Troccoli, A., Curto, G., Rappazzo, G. \& Tarasco, E., 2015. Entomopathogenic nematodes in Italy: Occurrence and use in microbial control strategies. In: Campos-Herrera, R. (ed). Sustainability in plant and crop protection: Ecology and applied technologies for sustainable plant and crop protection, Springer, Cham. pp. $431-449$

De Waal, J.Y., Malan, A.P., Levings, J. \& Addison, M.F., 2010. Key elements in the successful control of diapausing codling moth, Cydia pomonella (L.) (Lepidoptera: Tortricidae) in fruit bins with a South African isolate of Heterorhabditis zealandica (Rhabditida: Heterorhabditidae). Biocont. Sci. \& Technol. 20, 489-502. http://dx.doi.org/10.1080/09583151003599708

De Waal, J.Y., Malan, A.P. \& Addison, M.F., 2013. Effect of humidity and a superabsorbent polymer formulation on the efficacy of Heterorhabditis zealandica (Rhabditida: Heterorhabditidae) to control codling moth, Cydia pomonella (L.) (Lepidoptera: Tortricidae). Biocontrol Sci. Techn. 23, 62-78. http://dx.doi.org/10.1080/09583157.2012.736472 
De Waal, J.Y., Addison, M.F. \& Malan, A.P., 2017. Evaluation of a South African isolate of Heterorhabditis zealandica (Rhabditida: Heterorhabditidae) for the control of codling moth, Cydia pomonella (L.) (Lepidoptera: Tortricidae) in field applications. Int. J. Pest Manag. https:// doi.org/10.1080/09670874.2017.1342149

Deseo, K.V. \& Miller, L.A., 1985. Efficacy of entomogenous nematodes, Steinernema spp., against clearwing moths, Synanthedon spp., in North Italian apple orchards. Nematologica 31, 100-108.

Dlamini, T.M., Allshopp, E. \& Malan, A.P. 2019a. Entomopathogenic nematodes to control of western flower thrips, Frankliniella occidentalis (Thysanoptera: Thripidae), under laboratory conditions. Afr. Entomol. (In Press).

Dlamini, T.M., Allshopp, E. \& Malan, A.P. 2019b. Management of Frankliniella occidentalis (western flower thrips), and the potential use of entomopathogenic nematodes: a South African perspective. Afr. Entomol. (In Press).

Eidt, D.C. \& Dunphy, G.B., 1991. Control of spruce budmoth, Zeiraphera canadensis Mut. and Free., in white spruce plantations with entomopathogenic nematodes, Steinernema spp. Can. Entomol. 123, 379385 .

Ehlers, R.-U., 1996. Current and future use of nematodes in biocontrol: Practice and commercial aspects with regard to regulatory policy issues. Biocontrol Sci. Techn. 6, 303-316.

Ferreira, T. \& Malan, A.P., 2014a. Potential of entomopathogenic nematodes for the control of the banded fruit weevil, Phlyctinus callosus (Schönherr) (Coleoptera: Curculionidae). J. Helminthol. 88, 293-301. DOI:10.1017/ S0022149X13000175

Ferreira, T. \& Malan, A.P., 2014b. Xenorhabdus and Photorhabdus, bacterial symbionts of the entomopathogenic nematodes Steinernema and Heterorhabditis and their in vitro liquid mass culture: A review. Afr. Entomol. 22, 1-14. https://hdl.handle.net/10520/EJC150979

Finney, J.R. \& Walker, C., 1979. Assessment of a field trial using the DD-136 strain of Neoaplectana sp. for the control of Scolytus scolytus. J. Invertebr. Pathol. 33, 239-241.

Forschler, B.T. \& Nordin, G.L., 1988. Suppression of carpenterworm, Prionoxystus robiniae (Lepidoptera: Cossidae), with the entomophagous nematodes, Steinernema feltiae and Steinernema bibionis. J. Kansas. Entomol. Soc. 61, 396-400.

Gaugler, R., Bednarek, A. \& Campbell, J.F., 1992. Ultraviolet inactivation of heterorhabditid and steinernematid nematodes. J. Invertebr. Pathol. 160, 155-160.

Gaugler, R. \& Boush, G.M., 1978. Effects of ultraviolet radiation and sunlight on the entomogenous nematode, Neoaplectana carpocapsae. J. Invertebr. Pathol. 32, 291-296.

Georgis, R. \& Hague, N.G., 1988. Field evaluation of Steinernema feltiae against the web-spinning larch sawfly Cephalcia lariciphila. J. Nematol. 20, 317-320.

Glazer, I., 1992. Survival and efficacy of Steinernema carpocapsae in an exposed environment. Biocontrol Sci. Techn. 2, 101-107.

Glazer, I., Klein, M., Navon, A. \& Nakache, Y., 1992a. Comparison of efficacy of entomopathogenic nematodes combined with antidesiccants applied by canopy sprays against three cotton pests (Lepidoptera: Noctuidae). J. Econ. Entomol. 85, 1636-1641.

Glazer, I., Nakache, Y. \& Klein, M., 1992b. Use of entomopathogenic nematodes against foliage pests. Hassadeh 72, 626-630.

Glazer, I. \& Navon, A., 1990. Activity and persistence of entomoparasitic nematodes tested against Heliothis armigera (Lepidoptera: Noctuidae). J. Econ. Entomol. 83, 1795-1800.
Godfrey, G.H. \& Hoshino, H.M., 1933. Studies on certain environmental relations of the root-knot nematode, Heterodera radicicola. Phytopathology $23,41-62$.

Godfrey, K.E., Daane, K.M., Bentley, W.J., Gill, R.J. \& Malakar-Kuenen, R., 2002. Mealybugs in California vineyards. UCANR Publications, Oakland.

Greathead, D.J., Lionnet, J.F.G., Lodos, N. \& Whellan, J.A., 1971. A review of biological control in the Ethiopian region. Farnham Royal, Slough.

Grenier, E., Laumon, C. \& Abad, P., 1996a. Molecular characterization of two species-specific tandemly repeated DNAs from entomopathogenic nematodes Steinernema and Heterorhabditis (Nematoda: Rhabditida). Mol. Biochem. Parasitol. 83, 47-56.

Grenier, E., Bonifassi, E., Abad, P. \& Laumond, C., 1996b. Use of species-specific satellite DNAs as diagnostic probes in the identification of Steinernematidae and Heterorhabditidae entomopathogenic nematodes. Parasitol. 113, 483-489.

Grewal, P.S., Ehlers, R.-U. \& Shapiro-Ilan, D., 2005. Critical issues and research needs for expanding the use of nematodes in biocontrol. In: Grewal, P.S., Ehlers, R.U. \& Shapiro-Ilan, D.I. (eds). Nematodes as biocontrol agents. CAB International, Wallingford. pp. $479-498$.

Grewal, P.S., Selvan, S. \& Gaugler, R., 1994. Thermal adaptation of entomopathogenic nematodes: Niche breadth for infection, establishment, and reproduction. J. Therm. Biol. 19, 245-253.

Griffin, C.T., Boemare, N.E. \& Lewis, E.E., 2005. Biology and behaviour. In: Grewal, P.S., Ehlers, R.U. \& Shapiro-Ilan, D.I. (eds). Nematodes as biocontrol agents. CAB International, Wallingford. pp. $47-64$.

Hara, A.H., Kaya, H.K., Gaugler, R., Lebeck, L.M. \& Mello, C.L., 1993. Entomopathogenic nematodes for biological control of the leaf miner Liriomyza trifolii (Dipt.: Agromyzidae). Entomophaga 38, 359-369.

Harington, J.S., 1953. Observation on the biology, the parasites and the taxonomic position of the black maize beetle. S. Afr. J. Sci. 50, 11-14.

Harris, M.A., Begley, J.W. \& Warkentin, D.L., 1990. Liriomyza trifolii (Diptera: Agromyzidae) suppression with foliar applications of Steinernema carpocapsae (Rhabditida: Steinernematidae) and Abamectin. J. Econ. Entomol. 83, 2380-2384.

Hattingh, V. \& Moore, S.D., 2003. Mealybugs. In: Integrated production guidelines for export citrus: Integrated pest and disease management. Citrus Research International, Nelspruit. pp. 65 - 69. https://doi.org/10.1016/j. jip.2018.02.004

Hatting, J.L. \& Malan, A.P., 2017. Status of entomopathogenic nematodes in integrated pest management strategies in South Africa. In: AbdElgawad, M.M.M, Askary, T.H. \& Coupland, J. (eds). Biocontrol agents: Entomopathogenic and slug parasitic nematodes. CABI, Wallington. pp. $409-428$.

Head, J., Lawrence, A.J. \& Walters, K.F.A., 2004. Efficacy of the entomopathogenic nematode, Steinernema feltiae, against Bemisia tabaci in relation to plant species. J. Appl. Entomol. 128, 543-547.

Hussaini, S.S., 2002. Entomopathogenic nematodes for the control of crop pests. In: Upadhyay, R.K. (ed). Advances in microbial control of insect pests. Kluwer Academic/Plenum, Dordrecht. pp. 265 - 296.

Hussein, H., Adel, M. \& Gelbič, I., 2012. Effectiveness of the entomopathogenic nematode Steinernema feltiae in agar gel formulations against larvae of the Colorado potato beetle, Leptinotarsa decemlineata (Say.) (Coleoptera: Chrysomelidae). Cent. Eur. J. Biol. 7, 77-82. DOI:10.2478/s11535-011-0090-0

Jacques, R.P., 1967. Mortality of five apple insects induced by the nematode DD136. J. Econ. Entomol. 60, 741-743. 
James, M., Addison, P. \& Malan, A.P., 2018. Surveying and screening South African entomopathogenic nematodes for the control of the Mediterranean fruit fly, Ceratitis capitata (Wiedemann). Crop Prot. 105:41-28. DOI. org/10.1016/j.cropro.2017.11.008

Jones, T.J. \& Nita, M., 2016. Spatio-temporal association of GLRaV-3infected grapevines, and effect of insecticidal treatments on mealybug populations in Virginia vineyards. Eur. J. Plant. Pathol. 145, 885-900.

Kagimu, N., Ferreira, T. \& Malan, A.P., 2017. The attributes of survival in the formulation of entomopathogenic nematodes utilised as insect biocontrol agents. Afr. Entomol. 25, 275-291. http://www.bioone.org/doi/ abs/10.4001/003.025.0275

Kain, D.P. \& Agnello, A.M., 1999. Pest status of American plum borer (Lepidoptera: Pyralidae) and fruit tree borer control with synthetic insecticides and entomopathogenic nematodes in New York state. J. Econ. Entomol. 92, 193-200.

Kaya, H.K., Aguillera, M.M., Alumi, A., Choo, H.Y., De la Torre, M., Fodor, A., Ganguly, S., Hazir, S., Lakatos, T., Pye, A., Wilson, M., Yamanaka, S., Yang, H. \& Ehlers, R.-U., 2006. Status of entomopathogenic nematodes and their symbiotic bacteria from selected countries or regions of the world. Biol. Control 38, 134-155

Kaya, H.K. \& Brown, L.R., 1986. Field application of entomogenous nematodes for biological control of clear-wing moth borers in alder and sycamore trees. J. Arboric. 12, 150-154.

Kaya, H.K. \& Reardon, R.C., 1982. Evaluation of Neoaplectana carpocapsae for biological control of the western spruce budworm, Choristoneura occidentalis: Ineffectiveness and persistence of tank mixes. J. Nematol. 14, 595-597.

Kaya, H.K. \& Stock, S.P., 1997. Techniques in insect nematology. In: Lacey, L.A. (ed). Manual of techniques in insect pathology. Academic Press, London. pp. $281-324$.

Kaya, H.K., Aguillera, M.M., Alumi, A., Choo, H.Y., De la Torre, M., Fodor, A., Ganguly, S., Hazir, S., Lakatos, T., Pye, A., Wilson, M., Yamanaka, S., Yang, H. \& Ehlers, R.-U., 2006. Status of entomopathogenic nematodes and their symbiotic bacteria from selected countries or regions of the world. Biol. Control 38, 134-155.

Kaya, H.K., Hara, A.H. \& Reardon, R.C., 1981. Laboratory and field evaluation of Neoaplectana carpocapsae (Rhabditida: Steinernematidae) against the elm leaf beetle (Coleoptera: Chrysomelidae) and the western spruce budworm (Lepidoptera: Tortricidae). Can. Entomol. 113, 787-793.

Kaya, H.K., Joos, J.L. \& Falcon, L.A., 1984. Suppression of the codling moth (Lepidoptera: Olethreutidae) with the entomogenous nematode, Steinernema feltiae (Rhabditida: Steinernematidae). J. Econ. Entomol. 77, 1240-1244.

Krogh, K.A., Halling-Sørensen, B., Mogensen, B.B. \& Vejrup, K.V., 2003. Environmental properties and effects of nonionic surfactant adjuvants in pesticides: A review. Chemosphere 50, 871-901.

Kutamanyane, A., Ferreira, T. \& Malan, A.P., 2018. Bradysia species (Diptera: Sciaridae) as pests of covered crops, with special reference to biological control using entomopathogenic nematodes. Afr. Entomol. (In press).

Lacey, L.A., Frutos, R., Kaya, H.K. \& Vail, P., 2001. Insect pathogens as biological control agents: Do they have a future? Biol. Control 21, 230-248.

Lacey, L.A., Neven, L.G., Headrick, H.L. \& Fritts, R. Jr., 2005. Factors affecting entomopathogenic nematodes (Steinernematidae) for control of overwintering codling moth (Lepidoptera: Tortricidae) in fruit bins. J. Econ. Entomol. 98, 1863-1869.

Lacey, L.A. \& Georgis, R., 2012. Entomopathogenic nematodes for control of insect pests above and below ground with comments on commercial production. J. Nematol. 44, 218-225.
Langford, E.A., Nielsen, U.N., Johnson, S.N. \& Riegler, M., 2014. Susceptibility of Queensland fruit fly, Bactrocera tryoni (Froggatt) (Diptera:Tephritidae), to entomopathogenic nematodes. Biol. Control 69, 34-39.

LeBeck, L.M., Gaugler, R., Kaya, H.K., Hara, A.H. \& Johnson, M.W., 1993. Host stage suitability of the leafminer Liriromyza trifolii (Diptera: Agromyzidae) to the entomopathogenic nematode Steinernema carpocapsae (Rhabditida: Steinernematidae). J. Invertebr. Pathol. 62, 58-63.

Lee, D.W., Yang, J.Y., Han, G.Y., Choo, H.Y., Lee, S.M., Hyeong, H.K., Park, C.G. \& Choo, Y.M., 2006. Entomopathogenic nematodes for biological control of Pryeria sinica Moore (Lepidoptera: Zygaenidae) and persistence on Euonymus japonica Thunberg foliage. J. Asia-Pacific Entomol. 9, 195-172.

Le Vieux, P.D., 2013. Entomopathogenic nematodes for the control of the vine mealybug (Planococcus ficus) in South African wine and table grapes. Thesis, Stellenbosch University, Private Bag X1, 7602 Matieland (Stellenbosch), South Africa.

Le Vieux, P.D. \& Malan, A.P., 2013a. An overview of the vine mealybug (Planococcus ficus) in South African vineyards and the use of entomopathogenic nematodes as potential biocontrol agents. S. Afr. J. Enol. Vitic. 34, 108-118

Le Vieux, P.D. \& Malan, A.P., 2013b. The potential use of entomopathogenic nematodes to control Planococcus ficus (Signoret) (Hemiptera: Pseudococcidae). S. Afr. J. Enol. Vitic. 34, 296-306.

Le Vieux, P.D. \& Malan, A.P., 2015. Prospects for using entomopathogenic nematodes to control the vine mealybug, Planococcus ficus, in South African vineyards. S. Afr. J. Enol. Vitic. 36, 59-70.

MacVean, C.M., Brewer, J.W. \& Capinera, J.L., 1982. Field tests of antidesiccants to extend the infection period of an entomogenous nematode, Neoaplectana carpocapsae, against the Colorado potato beetle. J. Econ. Entomol. 75, 97-101.

Malan, A.P. \& Manrakan, A., 2009. Susceptibility of the Mediterranean fruit fly (Ceratitis capitata) and the Natal fruit fly (Ceratitis rosa) to entomopathogenic nematodes. J. Invertebr. Pathol. 100, 47-49. DOI:10.1016/j.jip.2008.09.007

Malan, A.P. \& Hatting, J.. 2015. Entomopathogenic nematode exploitation: Case studies in aboratory and field applications from South Africa In: Campos-Herrera R. (ed). Sustainability in plant and crop protection: Ecology and applied technologies for sustainable plant and crop protection, Springer, Cham. pp. $475-506$

Malan, A.P., Knoetze, R. \& Tiedt, L.R., 2016. Steinernema nguyeni n. sp. (Rhabditida: Steinernematidae), a new entomopathogenic nematode from South Africa. Nematology 18, 571-590. DOI:10.1163/15685411-00002978

Marrero, M.A., 2006. Nematodos entomopatogenos (Heterorhabditis spp.) para el control de Spodoptera frugiperda (J. E. Smith), Plutella xylostella (Linnaeus.) y Heliothis virescens (Fabricius) [MSc thesis]. Centro Agricola 33,90 .

Mason, J.M., Matthews, G.A. \& Wright, D.J., 1998. Screening and selection of adjuvants for the spray application of entomopathogenic nematodes against a foliar pest. Crop Prot. 17, 463-470.

Mgocheki, N. \& Addison, P., 2009. Effect of contact pesticides on vine mealybug parasitoids, Anagyrus sp. near A. pseudococci (Girault) and Coccidoxenoides perminutus (Timberlake) (Hymenoptera: Encyrtidae). S. Afr. J. Enol. Vitic. 30, 110-116.

Millar, I.M., 2002. Mealybug genera (Hemiptera: Pseudococcidae) of South Africa: Identification and review. Afr. Entomol. 10, 185-233.

Miller, L.A. \& Bedding, R.A., 1982. Field testing of the insect parasitic nematode, Neoaplectana bibionis (Nematoda: Steinernematidae) against currant borer moth, Synanthedon tipuliformis (Lep.: Sesiidae) in blackcurrants. Entomophaga 27, 109-114. 
Myburgh, A.C., Rust, D.J. \& Starke, L.C., 1973. Pests of Protea cut flowers. J. Entomol. Soc. S. Afr. 36, 251-255.

Nguyen, K., Malan, A. \& Gozel, U., 2006. Steinernema khoisanae n. sp. (Rhabditida: Steinernematidae), a new entomopathogenic nematode from South Africa. Nematology 8, 157-175.

Nouh, G.M. \& Hussein, M.A., 2014. The role of entomopathogenic nematodes as biocontrol agents against some tephritid flies. Adv. Biol. Res. (Rennes) 8, 301-306.

Nyasani, J.O., Kimenju, J.W., Olubayo, F.M. \& Wilson, M.J., 2008 Laboratory and field investigations using indigenous entomopathogenic nematodes for biological control of Plutella xylostella in Kenya. Int. J. Pest. Manage. 54, 355-361

Odendaal, D., Addison, M.F. \& Malan, A.P., 2015. Entomopathogenic nematodes for the control of the codling moth (Cydia pomonella L.) in field and laboratory trials. J. Helminthol. 20, 1-9. DOI:https://doi. org/10.4001/003.023.0224

Odendaal, D., Addison, M.F. \& Malan, A.P., 2016a. Evaluation of aboveground application of entomopathogenic nematodes for the control of diapausing codling moth (Cydia pomonella L.) under natural conditions. Afr. Entomol. 24, 61-74. DOI:https://doi.org/10.4001/003.024.0061

Odendaal, D., Addison, M.F. \& Malan, A.P., 2016b. Control of diapausing codling moth, Cydia pomonella (Lepidoptera: Tortricidae), in wooden fruit bins using entomopathogenic nematodes. Biocontr. Sci. \& Technol. 26, 1504-1515. DOI:https://doi.org/10.4001/003.023.0224

Platt, T., Stokwe, N.F. \& Malan, A.P., 2018. Potential of loca entomopathogenic nematodes for control of the vine mealybug, Planococcus ficus. S. Afr. J. Enol. Vitic. 39, 208-215. DOI: http://dx.doi. org/10.21548/39-2-3158

Platt, T., Stokwe, N.F. \& Malan, A.P., 2019a. Foliar application of Steinernema yirgalemense to control Planococcus ficus: Assessing adjuvants to improve efficacy. S. Afr. J. Enol. Vitic.. S. Afr. J. Enol. Vitic. 40, 13-19. DOI: http://dx.doi.org/10.21548/40-1-2920

Platt, T., Stokwe, N.F. \& Malan, A.P., 2019b. Grapevine leaf application of Steinernema yirgalemense to control Planococcus ficus in vineyards conditions. S. Afr. J. Enol. Vitic. 40 (1): $75-83$ DOI: https://doi. org/10.21548/40-1-3141

Prinsloo, G.L. \& Uys, V.M., 2015. Insects of Cultivated Plants and Natural Pastures in Southern Africa. Entomological Society of Southern Africa, Hatfield, South Africa.

Rodríguez, M.G., Enrique, R., Gómez, L., Hernández-Ochandía, D., Miranda, I., Hernández, A., Díaz-Viruliche, L., González, E. \& Rosales, L.G., 2013. Impact of entomopathogenic nematode applications on diamond back moth population. Rev. Protec. Vegetal. 28, 158-160.

SATI (South African Table Grape Industry), 2015. Statistics Booklet. SATI, Paarl, South Africa.

Schroer, S. \& Ehlers, R-U., 2005. Foliar application of the entomopathogenic nematode Steinernema carpocapsae for biological control of diamondback moth larvae (Plutella xylostella). Biol. Control 33, 81-86.

Shannag, H.K. \& Capinera, J.L., 1995. Evaluation of entomopathogenic nematode species for the control of melonworm (Lepidoptera: Pyralidae). Environ. Entomol. 24, 143-148.

Shapiro-Ilan, D.I., Cottrell, T.E., Mizell, R.F. \& Horton, D.L., 2016.

Efficacy of Steinernema carpocapsae plus fire gel applied as a single spray for control of the lesser peachtree borer, Synanthedon pictipes. Biol. Control 94, 33-36.

Shapiro-Ilan, D.I., Cottrell, T.E., Mizell, R.F., Horton, D.L., Behle, R.W. \& Dunlap, C.A., 2010. Efficacy of Steinernema carpocapsae for control of the lesser peachtree borer, Synanthedon pictipes: Improved aboveground suppression with a novel gel application. Biol. Control 54, 23-28.
Shapiro-Ilan, D.I., Gouge, D.H., Piggott, S.J. \& Fife, J.P., 2006. Application technology and environmental considerations for use of entomopathogenic nematodes in biological control. Biol. Control 38, 124-133.

Shapiro-Ilan, D.I. \& Mizell, R.F., 2012. Laboratory virulence of entomopathogenic nematodes to two ornamental plant pests, Corythucha Ciliata (Hemiptera: Tingidae) and Stethobaris Nemesis (Coleoptera: Curculionidae). Fla. Entomol. 95, 922-927.

Somvanshi, V.S., Ganguly, S. \& Paul, A.V.N., 2006. Field efficacy of the entomopathogenic nematode Steinernema thermophilum Ganguly and Singh (Rhabditida: Steinernematidae) against diamondback moth (Plutella xylostella L.) infesting cabbage. Biol. Control 37, 9-15.

Spaull, V.W., 1992. On the use of a methylcellulose polymer to increase the effectiveness of a Heterorhabditis species against the sugarcane stalk borer, Eldana saccharina. Fundam. Appl. Nematol. 15, 457-461.

Steyn, W.P., Knoetze, R., Tiedt, T.R. \& Malan, A.P., 2017a. Steinernema litchii n. sp. (Rhabditida: Steinernematidae), a new entomopathogenic nematode from South Africa. Nematology 19, 1157-1177. DOI: https://doi. org/10.1163/15685411-00003116

Steyn, W.P., Malan, A.P., Daneel, M.S. \& Slabbert, R.M., 2017 b. Entomopathogenic nematodes from north-eastern South Africa and their virulence against the false codling moth, Thaumatotibia leucotreta (Lepidoptera: Tortricidae). Biocontr. Sci. Technol. 27, 1265-1278. DOI:http://dx.doi.org/10.1080/09583157.2017.1391174

Steyn, L.A.I., Addison, A. \& Malan, A.P. 2019. South African entomopathogenic nematodes to control the leaf miner, Holocacista capensis (Lepidoptera: Heliozelidae). S. Afr. J. Enol. Vitic. (In Press).

Stokwe, N.F. \& Malan, A.P., 2016. Susceptibility of the obscure mealybug, Pseudococcus viburni (Signoret) (Pseudococcidae), to South African isolates of entomopathogenic nematodes. Int. J. Pest Manage. 62, 119-128.

Stowens, D., 1942. The effects of ultraviolet irradiation on Trichinella spiralis. Am. J. Hyg. 36, 264-268.

Tofangsazi, N., Cherry, R.H. \& Arthurs, S.P., 2014. Efficacy of commercial formulations of entomopathogenic nematodes against tropical sod webworm, Herpetogramma phaeopteralis (Lepidoptera: Crambidae). J. Appl. Entomol. 138, 656-661. DOI:doi/10.1111/jen.12125

United States (US) Environmental Protection Agency (EPA), 2015. Pesticide Registration Manual. US EPA, Washington, D.C

Unruh, T.R. \& Lacey, L.A., 2001. Control of codling moth, Cydia pomonella (Lepidoptera: Tortricidae), with Steinernema carpocapsae: Effects of supplemental wetting and pupation site on infection rate. Biol. Control. 20, 48-56.

Van Damme, V.M., Beck, B.K.E.G., Berckmoes, E., Moerkens, R., Wittemans, L., De Vis, R., Nyuttens, D., Casteels, H.F., Maes, M., Tirry, L. \& De Clerq, P., 2016. Efficacy of entomopathogenic nematodes against larvae of Tuta absoluta in the laboratory. Pest Manag. Sci. 72, 1702-1709. DOI: $10.1002 /$ ps.4195

Van Niekerk, S. \& Malan, A.P., 2012. Potential of South African entomopathogenic nematodes (Heterorhabditidae and Steinernematidae) for control of the citrus mealybug, Planococcus citri (Pseudococcidae). J. Invertebr. Pathol. 111, 166-174. DOI:http://dx.doi.org/10.1016/j. jip.2012.07.023

Van Niekerk \& Malan, A.P., 2013. Adjuvants to improve aerial control of the citrus mealybug Planococcus citri (Hemiptera: Pseudococcidae) using entomopathogenic. J. Helminth. 98, 189-195. DOI:10.1017/ S0022149X13000771

Van Niekerk, S. \& Malan, A.P., 2014a. Compatibility of biological control agents and agrochemicals to entomopathogenic nematodes, Steinernema yirgalemense and Heterorhabditis zealandica. Afr. Entomol. 22, 49-56. https://doi.org/10.4001/003.022.0132 
Van Niekerk, S. \& Malan, A.P., 2014b. Evaluating the efficacy of a polymer-surfactant formulation to improve control of Planococcus citri (Risso) (Hemiptera: Pseudococcidae) under simulated natural conditions. Afri. Plant Protec. 17, 1-9. http://reference.sabinet.co.za/sa epublication/ plantpro

Van Niekerk, S. \& Malan, A.P., 2015. Adjuvants to improve aerial control of the citrus mealybug Planococcus citri (Hemiptera: Pseudococcidae) using entomopathogenic nematodes. J. Helminthol. 89, 189-195. DOI:10.1017/ S0022149X13000771

Vincent, C. \& Bélair, G., 1992. Biocontrol of the apple sawfly, Hoplocampa testudinea, with entomogenous nematodes. Entomophaga 37, 575-582.

Wakgari, W.M. \& Giliomee, J.H., 2004. Mealybugs and their parasitoids in apple and pear orchards in the Western Cape Province, South Africa. Afr. Plant Prot. 10, 7-11.

Walton, V.M., 2003. Development of an integrated pest management system for vine mealybug, Planococcus ficus (Signoret), in vineyards in the Western Cape Province, South Africa. Thesis, Stellenbosch University, Private Bag X1, 7602 Matieland (Stellenbosch), South Africa.

Walton, V.M., Daane, K.M. \& Pringle, K.L., 2004. Monitoring Planococcus ficus in South African vineyards with sex pheromone-baited traps. Crop Prot. 23, 1089-1096. DOI:10.1016/j.cropro.2004.03.016

Walton, V.M. \& Pringle, K.L., 1999. Effects of pesticides used on table grapes on the mealybug parasitoid Coccidoxenoides peregrinus (Timberlake) (Hymenoptera: Encyrtidae). S. Afr. J. Enol. Vitic. 20, 31-34.

Walton, V.M. \& Pringle, K.L., 2004. Vine mealybug, Planococcus ficus (Signoret) (Hemiptera: Pseudococcidae), a key pest in South African vineyards. A review. S. Afr. J. Enol. Vitic. 25, 54-62.

Welch, H.E. \& Briand, L.J., 1961. Tests of the nematode DD 136 and an associated bacterium for control of the Colorado potato beetle, Leptinotarsa decemlineata (Say). Can. Entomol. 93, 759-763.
Williams, E.C. \& Macdonald, O.C., 1995. Critical factors required by the nematode Steinernema feltiae for the control of the leafminers, Liriomyza huidobrensis, Liriomyza bryoniae and Chromatomyia syngenesiae. Ann. Appl. Biol. 127, 329-341.

Williams, E.C. \& Walters, K.F.A., 1994. Nematode control of leafminers Efficacy, temperature and timing. In: Brighton Crop Protection Conf., Pests and Diseases, vol 3(3). United Kingdom. Department for Environment, Food and Rural Affairs, London. pp. 1005 - 1012.

Williams, E.C. \& Walters, K.F.A., 2000. Foliar application of the entomopathogenic nematode Steinernema feltiae against leafminers on vegetables. Biocontrol Sci. Techn. 10, 61-70. DOI:http://dx.doi. org/10.1080/09583150029396

Wilson, M. \& Gaugler, R., 2004. Factors limiting short-term persistence of entomopathogenic nematodes. J. Appl. Entomol. 128, 250-253. DOI:10.1111/j.1439-0418.2004.00814.x

Wright, D.J., Peters, A., Schroer, S. \& Fife, J.P., 2005. Application technology. In: Grewal, P.S., Ehlers, R.U. \& Shapiro-Ilan, D.I. (eds). Nematodes as biocontrol agents. CAB International, Wallingford. pp. 91 -106 .

Yamanaka, S., Seta, K. \& Yasuda, M., 1986. Evaluation of the use of entomogenous nematode, Steinernema feltiae (str. Mexican) for the biological control of the fall webworm, Hyphantria cunea (Lepidoptera: Arctiidae). Jpn. J. Nematol. 16, 26-31.

Zolfagharian, M., Saeedizadeh, A., Abbasipour, H., Ali Joyandeh, A. \& Yazdi, A.A., 2014. Efficacy of entomopathogenic nematode, Steinernema carpocapsae against the diamondback moth, Plutella xylostella (L.) in laboratory condition. Arch. Phytopathol. Plant Prot. 48, 393-399. DOI: http://dx.doi.org/10.1080/03235408.2014.893632 